\title{
Legal Implications For Notary Who Does Not Attach The Fingerchop On Original Agreement
}

\author{
Edi Adi Ambarawa ${ }^{1}$, Yudi Hendarto ${ }^{2}$ and Djauhari ${ }^{3}$
}

\begin{abstract}
This study aims to find out the background of the attachment of fingerchops to the Original Agreement and legal implications for Notary who do not attach it. This study used the normative legal research method, through the approach of law to gain views and doctrine as the basis of legal argument on legal issues studied. Based on the results, it can be seen that the background attached fingerchop tap on the Original Agreement aims to anticipate when the applicant denied his signature. Thus, as additional evidence uses fingerchops. Legal implications for a Notary who does not attach a fingerchop to the Original Agreement may be subject to sanctions in accordance with Article 16 paragraph (11) of Notary Law: (a) written notice; (b) temporary dismissal; (c) dismissal with respect; (d) dismissal with disrespect. If a written warning sanction to a Notary is not complied with or violated by the Notary concerned, then the following sanctions may be imposed in stages.
\end{abstract}

Keywords: Notary; Fingerchop; Original Agreement.

\section{Introduction}

In the explanation of the Notary Public Law, it is explained that: 4 "Authentic agreements essentially contain formal truths in accordance with what the parties notify the Notary. However, a Notary has an obligation to include that what is contained in the Notarial agreement is fully understood and in accordance with the wishes of the parties, that is by reading it so that it becomes clear the, as well as providing access to information, including access to legislation which are related to the signatories of the agreement. Accordingly, the parties may decide freely to approve or disapprove the contents of the notarial agreement they sign. "

In the era of globalization, regional autonomy and free market nowadays, the citizens need a quality Notary. The quality includes the quality of science, as well as the quality of morality and ethics, and upholds the dignity in providing legal services to the community.

The Notary Law regulates in detail about the general position held by the Notary, so that an authentic agreement "made by" or "made before" Notary can guarantee the legal certainty, public order and legal protection.

Legal needs in the community can be seen from the increasing number of agreements formulated by the parties in a notarial agreement. The Agreement constitutes a legal act which has legal consequences. "The agreement may be interpreted as an act of obtaining a set of rights and obligations and having legal consequences which are the consequence of violation of such rights and obligations".

\footnotetext{
1 Master of Notary's Student, Faculty of Law, Universitas Islam Sultan Agung email edyadyambarawa@gmail.com

2 Students of Master of Law, Faculty of Law, Universitas Islam Sultan Agung email numana.iphone7@icloud.com

${ }^{3}$ Lecturer of Faculty of Law UNISSULA

${ }^{4}$ Act No 2 / 2014 Public Notary Law.
} 
In the course of performing his duties, the Notary is obliged to keep any information or remarks given before him in connection with the agreement. Maintaining confidentiality is one form of Notary obligations as stipulated by the Law of Notary Position.

In carrying out his duties and positions, the Notary shall also: "act honestly, thoroughly, independently, impartially, and safe the interests of the parties concerned in the conduct of the law". ${ }^{5}$ If it is related to a agreement made "by" or "before" Notary, in accordance with Article 16 paragraph (1) letter c of Notary Law, the Notary is obliged: "to attach letters and documents and fingerchops to the Original Agreement (Minuta Akta)".

In Article 1 Sub-Article 8 of the Notary Law is stipulated on the understanding of Original Agreement. "Akta Minuta is the original agreement which includes the signatures of the applicant, witnesses, and Notaries, which are kept as part of the Notary Protocol". 6

Based on the above understanding, it is contained the will of the Law of Official Notary that in Original Agreement needs the signatures of the applicants not the fingerchops, which has been regarded as a substitute for signatures. The Notary Law does not stipulate the possibility of an Original Agreement without the applicant's signature, since the only applicant or all of the applicant cannot sign, either because of illness or physical disability.

In the closing of the Notary Law, Article 38 Paragraph (4) Sub-Paragraph b of the Notary Public Procedure Law states that the end of the agreement contains: "a description of the signing and the signing or translation of the agreement if any ${ }^{7 " \text { ". In }}$ the above article, it does not mention at all about the inclusion of fingerchops.

Based on the background description, the researcher formulated some problems in this paper, which are as follows: What is the background of attaching fingerchops tap on the Original Agreement? What is the legal implication for a Notary who does not attach fingerchops to the original agreement?

\section{Research Methods}

The research method used in this paper was the normative legal research. According to Peter Mahmud Marzuki24 that normative legal research is "a process of finding a rule of law, legal principles, and legal doctrines to address the legal issues faced"'s.

This paper used statute approach, the legislation in question is Act No. 2 of 2014 About Amendment to Act No. 30 Of 2004 Concerning Notary Position (hereinafter referred to as Notary Position Law) and Proceedings Draft Law on Notary Offices, this approach was done by reviewing the law as the object of the issue and as a basis for a foundation to provide arguments for the legal issues under investigation.

\footnotetext{
${ }^{5}$ Indonesia Legal Center 2009 Himpunan Peraturan Perundang-Undangan Jabatan Notaris \& PPAT Karya Gemilang Jakarta p.8.

${ }^{6}$ Ibid

${ }^{7}$ Ibid

8 Hidayatullah, Gunarto, Anis Mashdurohatun and Ahmad Rofiq, "Ideal Reconstruction of Law Number 41 Year 2004 on the Position and the Authority of Money Wakaf Law Based on Justice Values Towards Improving the Moslem Economyc", in International Journal of Economic Research, Volume 14 Number 152017 p. 317
} 


\section{Discussion}

\subsection{The Background of Attaching the Fingerchop on the Original Agreement}

With regard to the evidence of presence before the Notary, fingerchops are also deemed necessary. Moreover, the Notary Law has been arranged, especially if the sole constraint or all the applicants cannot sign it. The proof is fingerchop but does not mention fingerchops between them.

The various interpretations and opinions about the synchronization of the two articles become legal issues among Notaries. Some notaries said the inclusion of fingerchops on the original agreement is mandatory under the provisions of Article 16 paragraph (1) letter $c$ of the Notary Law without having to relate it to the provisions of Article 1 number 8 of the Notary Position Law. Some argue that the inclusion of fingerchops because the parties cannot sign or they are illiterate. However, there also notary who says that it is okay to put or not to put the fingerchop on the original agreement.

Every Notary must be a decision maker in determining attitudes towards all matters relating to the duties of his position as a Notary. A Notary does not need to wait for command or opinion of others about what to do in carrying out his duties.

The provision of Article 16 Paragraph (1) Sub-Paragraph c of the Notary Public Law concerning Notary's obligation to attach fingerchop to the Original Agreement, if it is related to positivism legal theory, it should be implemented, because according to this theory "law is a law order". Because of the obligation to attach the fingerchops is a command of the Notary's Office Law, there should be no dissenting opinions among the notaries.

If you look at the Draft Law on Notary Offices, the background of attaching applicant's fingerchops on the original agreement is due to the many experiences of the government-in this case represented by the Ministry of Justice and Human Right. The government faces cases in court such as the objections of the parties, shareholders and so on, voters who lose their assets in a matter of days, even without selling their asset and grant.

The government imposes the notary to cancel their agreement, but it cannot be done. Since the Notary cannot cancel the agreement, whereas if the notarial agreement is supported by any fake facts, the agreement can be canceled. It is no longer has to wait for the court decision.

Therefore, the government hopes that all the parties take fingerchops and there is documentation, so the notary is convinced that the party who comes and takes fingerchop is the true applicant. It is true that the person A is not the B who claimed as $A$, because it has a lot of cases and it is quite disturbing the business climate in Indonesia.

If it is seen the history of the formation of the Draft Law on the Position of Notary, there is a difference of Notary obligation as referred to in Article 16 paragraph (1) letter $\mathrm{c}$ of the Notary Position Law. In the draft of the People's Legislative Assembly of the Republic of Indonesia (DPR RI), it is mentioned to attach letters and documentation of the parties in the form of visual images and facts. While in the 
government draft (Ministry of Justice and Human Right), it is said to attach letters, documents and fingerchops to the Original Agreement.

If we analyze deeper, the letter is a writing containing meaning, both intended as evidence and not intended as evidence, made on paper or other means. While the document is all the text or images that can be used for an interest. In other words, the definition of the document is more extensive when compared with the letter, because in the document including pictures, photos, and so forth.

Furthermore, the meaning contained in the phrase "attaching fingerchops of the parties", then the sentence can be interpreted as "attach a document containing fingerchops of the parties". The meanings contained in the provisions are letters and documents relating to or related to the identity of the parties, as well as documents containing fingerchops of the parties.

The use of the term "attaching fingerchops to the Original Agreement" is less common, since the common attachment to Original Agreement is letters and documents. If it is intended to attach fingerchops, then the term used is not attach but give..

Embedding documents containing fingerchops cannot be separated from the notion of Original Agreement, which expressly stipulates that those listed by the applicants/parties, witnesses, and notary is in the form of signatures, not fingerchops.

Answering the Original Agreement question of how the Notary should address the stipulation of the fingerchop, there is no provision that forbids a Notary to apply his opinion or interpretation whether or not to include fingerchops, or depending on the circumstances.

The most important thing is that the parties are willing to put fingerchops when it is requested by the notary in question. Notary must also be consistent with his decision during his duties and positions.

Considering the Draft Law concerning Notary Position in relation to the enactment of Act No. 2 Of 2014 concerning Amendment to Act No. 30 Of 2004 regarding Notary Office (UUJN), particularly Article 16 paragraph (1) letter c, applicant's fingerchops on the Original Agreement is to identify the presence of the parties.

Requiring the applicants to attach fingerchops to the Original Agreement aims to anticipate if at any time the parties deny their signature on Original Agreement, then as additional evidence used the fingerchops.

Embedding fingerchop documents on the Original Agreement is inagreement a benefit and is a cautious attitude. However, if the obligation to attach the fingerchop document is obliged to the applicants/parties who can affix their signature, the obligation should also apply to the witnesses, because the existence of the witnesses is one of the requirements of the authenticity of a notary agreement.

Some Notaries interpret article 16 paragraph (1) sub-paragraph c of Notary Law differently. Among others are associated with article 1874 of the Civil Code, that the fingerchops are identical with the thumbprint. Whereas the affixing of the thumbprints referred to in Article 1874 of the Civil Code is intended for non-signatories. Likewise provisions Staatsblad Number 276, that thumbprint used as a substitute for signatures.

\subsection{Legal Consequences In the event of a Violation of the Code of Ethics by a Notary}


In Article 16 Paragraph (1) Sub-Paragraph c of the Notary Law, it is explained about the existence of Notary obligation, and violating the provisions as meant in the article may be subject to sanctions in accordance with Article 16 paragraph (11) of Notary Law, namely:

- Written warning

- Temporary dismissal

- Dismissal with respect

- Dismissal with disrespect

Sanctions contained in Article 16 paragraph (11) of the Notary Law, for violation of Article 16 paragraph (1) letter c can be categorized as administrative sanctions. This sanction is a sanction against a Notary relating to a agreement made by Notary. There are certain requirements or certain actions that are not done or not fulfilled by a Notary in performing his/her duties in the form of obligations contained in the Law of Notary Public.

In general, administrative sanctions can be distinguished 3 (three) kinds, namely: ${ }^{9}$

- Reparative Sanctions

This sanction is aimed at improving the violation of the rule of law. It may be the cessation of prohibited conduct, the obligation of a change of attitude/action so as to achieve the prescribed state of origin, the act of fixing something contrary to the rule. For example, the compulsion to do something for the government and the payment of forced money is determined as a punishment.

- Punitive Sanctions

Penal sanctions are an additional burden. Penal sanctions are in retaliation, and preventive actions that cause fear to the same offender or possibly other offenders. For example, a fine payment to the government and a severe reprimand.

- Regressive Sanctions

Regressive sanctions in response to disobedience, the abolition of the right to something decided by law, as if restored to the true state of law before a decision is made. For example, revocation, alteration or suspension of a Decision.

The sanctions contained in Article 16 paragraph (11) of the Notary's Office Law are in stages starting from written warnings to dismissal with disrespect. Such sanctions shall be imposed only if the Notary is proven to violate the provisions of certain Articles.

In Article 16 Paragraph (11) of the Notary Public Law on the violation of the obligation of a Notary to attach "fingerchops to the Original Agreement" in accordance with article 16 paragraph (1) letter c of the Notary Law. The notary shall be subjected to sanctions as described above, ranging from written warnings to dismissal with disrespect.

Article 16 paragraph (11) of the Notary's Office Law places a written warning at the first place in the imposition of sanctions. This is a warning to a Notary that if not met or violation is followed up with written reprimand sanctions. If such a sanction is not complied with by the Notary concerned, then it may be subject to subsequent sanctions in stages.

\footnotetext{
${ }^{9}$ Habib Adjie 2008 Hukum Notaris Indonesia Refika Aditama Bandung p. 211
} 
Placement of sanctions is in the form of written warning as the beginning to impose further sanctions not including administrative sanctions. In administrative sanctions is in the form of government coercion, prior to imposition of sanctions should be preceded by a written warning, this is included as a real aspect of coercive procedures. 10

The exercise of written warning aims to examine the accuracy between written warnings and violations made under applicable law. In the execution of a written warning grants the rights of those who are given such written warning to defend themselves in an administrative effort in the form of an objection or administrative appeal.

The formulation of sanctions in the form of a written warning is incorrectly incorporated as a sanction, but is only an initial stage for imposing real coercive sanctions which for the latter if proven to be subject to other sanctions.

Sanctions to the Notary in the form of temporary dismissal from his/her position shall be the next stage after the written sanction. The position of sanctions in the form of temporary dismissal from the position of Notary or suspension is the waiting period for the implementation of government coercion sanction. ${ }^{11}$

Sanction of a temporary dismissal of a Notary from his/her position is meant that the Notary does not perform his/her duties temporarily, before the sanction of dismissal with respect or dismissal is disrespected to the Notary.

The provision of this temporary dismissal shall terminate in the form of a remedy to the Notary to perform his duties and positions again or be followed up with dismissal sanctions with respect or dismissal with disrespect. ${ }^{12}$

A temporary dismissal of a Notary from his position means that the Notary concerned has temporarily lost his authority, and the Notary concerned cannot make any agreement or the Notary cannot perform his/her job duties. This needs to be limited by reason to await the result of examination of Notary Supervisory Board.

In enforcing administrative sanctions to the Notaries who become the watch instrument is the Supervisory Board that takes preventive measures aimed at preventing the occurrence of errors and irregularities in a legal act. ${ }^{13}$

Preventive measures shall be undertaken by conducting periodical examinations, it can be done 1 (one) time in a year or at any time deemed necessary to examine the compliance of a Notary in the performance of his/her duties which is observed by the examination of the protocol by the Local Supervisory Board (MPD). Then the MPD may inform the Regional Supervisory Board (MPW), if the report received by the MPD finds a criminal element. Furthermore, a hearing can be held to check the alleged violation of the Notary's Code of Ethics or the violation of the performance of Notary's office. If the results of the MPD examination find violations, the MPD cannot impose a repressive sanction on the Notary, but the MPD may only report to the MPW. ${ }^{14}$

\footnotetext{
${ }^{10}$ Ibid p.234

${ }^{11}$ Ibid

12 Habib Adjie 2011 Aspek Pertanggungjawaban Notaris dalam Pembuatan Akta Mandar Maju Bandung p.219.

${ }^{13}$ Ibid p. 223

${ }^{14}$ Ibid
} 
MPW (Regional Supervisory Broad) can undertake preventive measures, namely to conduct hearings to examine and take decisions on community reports submitted through MPW and to call Notary as a reporter for examination and to decide on the results of MPD examination.

MPW can perform repressive steps, namely to impose sanctions in the form of oral or written warning and this sanction is final. Propose sanction against Notary to Central Supervisory Board (MPP) in the form of: (1) temporary dismissal 3 (three) months up to 6 (six) months, or (2) dismissal with disrespect.

MPP does not undertake preventive action, namely conducting a hearing to examine and take decisions on appeal against the imposition of sanctions and refusals of leave, but repressive measures in the form of imposing sanctions on suspension, and proposing the imposition of sanctions in the form of dismissal of Notary with disrespect to the Minister. ${ }^{15}$

Sanctions directed against Notary is also awareness that the Notary in performing his duties of office has violated the provisions concerning the execution of duty of Notary office as stated in the Law of Notary Position.

In addition, the granting of sanctions to the Notary is also to protect the public from the act of Notary which may be harmful, for example in the making of agreement which does not protect the rights concerned as mentioned in Notarial Agreement.

Sanction against Notary to keep the dignity of Notary institution as trust institution, because if Notary do violation, it can decrease public trust to Notary Public. Individually sanction against Notary is a nightmare and bets in carrying out their duties, whether people still want to entrust the making of the agreement to the Notary concerned or not.

\section{Conclusion}

Based on writings analyzed by the authors, it can be concluded that: Background attached fingerchop on the Original Agreement is to identify the presence of the perties. Proof of presence that comes to the Notary is the person concerned who wants to make notarial agreement, not others. It is required to attach fingerchops to the Original Agreement of Notarial Agreement aimed to anticipate if in the next day there any party is denied his signature on Original Agreement of Notary, then as additional evidence used the fingerchop. Legal implications for a Notary who does not attach a fingerchop to the Original Agreement may be subject to sanctions in accordance with Article 16 paragraph (11) of Notary Law. This sanction is a sanction against a Notary relating to a agreement made by Notary. If the sanction of a written warning to the Notary is not complied with or violated by the Notary concerned, then it may be subject to subsequent sanctions in stages.

\section{References}

[1] Gunardi \&Markus Gunawan 2007 Kitab Undang-Undang Hukum Kenotariatan Raja Gravindo Persada Jakarta.

${ }^{15}$ Ibid 
[2] Habib Adjie 2008 Hukum Notaris Indonesia Refika Aditama Bandung.

[3] Hans Kelsen 2009 Teori Umum Tentang Hukum dan Negara Nusa Media Bandung.

[4] Hidayatullah, Gunarto, Anis Mashdurohatun and Ahmad Rofiq, "Ideal Reconstruction of Law Number 41 Year 2004 on the Position and the Authority of Money Wakaf Law Based on Justice Values Towards Improving the Moslem Economyc", in International Journal of Economic Research, Volume 14 Number 152017

[5] Herlien Budiono 2008 Kumpulan Tulisan Hukum Perdata di Bidang Kenotariatan Citra Aditya Bakti Bandung.

[6] Herlien Budiono \& Albertus Sutjipto 2005 Beberapa Catatan Mengenai UndangUndang Jabatan Notaris Indonesian Notary Asosiation Bandung.

[7] Indonesia Legal Center 2009 Himpunan Peraturan Perundang-Undangan Jabatan Notaris \& PPAT Karya Gemilang Jakarta.

[8] Philipus M.Hadjon 1992 Pemerintahan Menurut Hukum Yuridika Surabaya. 